\title{
DE GEVOLGEN VAN EEN FOUT BIJ HET SNOEIEN VAN LAANBOOMEN.
}

Het snoeien van laanboomen geschiedt vaak zeer onoordeelkundig. Een van de fouten, die daarbij dikwijls worden begaan, is deze, dat men een klein stompje van den afgehouwen tak laat zitten, inplaats dat men den tak geheel tot aan den stam wegneemt. (In nevensgaande figuur stelt $A$ de verkeerde, $B$ de goede manier van wegneming van een tak voor). En verder doet men vaak aan de wondvlakte niets. Dat laatste is ook eene geheel verkeerde manier van doen; want dan blijft
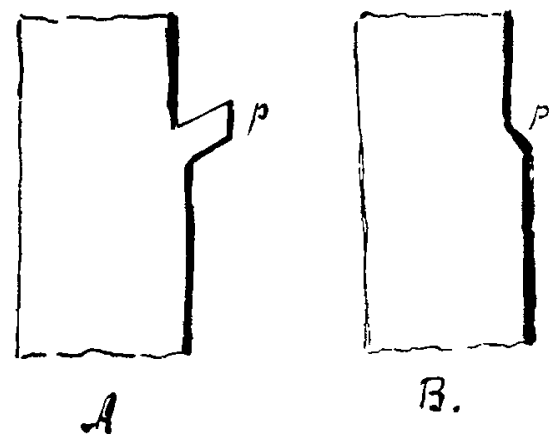

B. de wondvlakte aan allerlei schadelijke invloeden blootgesteld. Vooreerst aan den invloed van de weersgesteldheid, met name aan langdurige nattigheid en aan groote temperatuurwisseling; en ten tweede aan de inwerking van zulke parasiteerende organismen (zwammen en insekten), die uitsluitend of hoofdzakelijk door open wonden het houtlichaam binnentreden. Eene eerste noodzakelijkheid is dus: dat men de wondvlakte met teer bestrijkt, waardoor die schadelijke invloeden worden verwijderd gehouden. Ik wil daarover hier echter niet uitweiden; maar wel wil ik er iets uitvoeriger over spreken, waarom het zoo gevaarlijk is, dat men een stompje van den verwijderden tak laat zitten.

Zoo'n stompje (zie bijgaande figuur $A$, bij $p$ ) gaat in de meeste gevallen dood. Alleen bij zulke boomen, die -- zooals 
wilgen en populieren - zeer gemakkelijk snelgroeiende "waterloten" vormen, blijft het in leven. Deze loten toch zijn bebladerd; de bladeren nemen koolzuur uit de lucht op en trekken door de verdamping aan hunne oppervlakte water met voedende stoffen uit den stam tot zich. Het stompje van den afgehouwen tak ontvangt derhalve water en voedende stoffen genoeg om te blijven leven.

Maar vormen zich geen waterloten aan het stompje, dan ontvangt dit geen water en geen voedsel en begint het dus langzamerhand af te sterven; en er vestigt zich de zwam van het zoogenaamde ,roode vuur" (Nectria cinnabarina Fr.) in, die echter bij vele boomen niet tot takstompen beperkt blijft, maar weldra ook in den levenden stam overgaat en dezen aantast.

De bedoelde zwam leeft bij voorkeur in dood hout, bijv. in twijgen, takken of stammen, die door vorst of door eene andere oorzaak gedood zijn. Door de eene of andere wonde (bijv. door een snoeiwonde, een vorstspleet of een door een insekt veroorzaakte opening) dringt de zwam binnen; de zwamdraden groeien eerst in de houtvaten, maar gaan weldra ook in andere deelen van het hout, o.a. in de mergstralen over, het daar aanwezige zetmeel verbruikend, en het hout zwart kleurend. Tegen den herfst of wel gedurende een zachten winter, soms pas in 't voorjaar, begeven zich de zwamdraden naar de bast, waaruit weldra in grooten getale oranjekleurige, steenroode of vermiljoenroode wratjes of puistjes te voorschijn komen. Dat zijn voorplantingsorganen van de zwam (zwamkussentjes, waarop zich conidiën in menigte vormen). Later in 't voorjaar of in den zomer komen, ten deele vlak naast de eerstgenoemde wratjes, ten deele op andere plaatsen van den stam, meer donkerroode, karmijnkleurige, iets hardere korreltjes voor den dag, die vaak in heele groepen bijeenzitten. Dat zijn een andere soort van voortplantingsorganen van dezelfde zwam (peritheciën, waarbinnen zich de asci bevinden, die ascosporen bevatten). 
Vooral de eerstvermelde oranjekleurige, steenroode of vermiljoenroode wratten of puisten vallen reeds van uit de verte op doode twijgen, takken en stammen zeer in 't oog. Men spreekt dan van het "roode vuur".

Dat zoogenaamde "roode vuur" nu vestigt zich op de stompjes, die bij de wegneming van takken zijn blijven zitten en afsterven. Maar van daar uit gaat later de zwam, welke de oorzaak van het bovenvermelde verschijnsel is, vaak in den levenden stam over, die weldra, het eerst in de nabijheid van het stompje, het "roode vuur" begint te vertoonen; voortdurend breidt de zwam zich dan verder in den stam uit, vooral naar boven toe, maar toch ook wel naar beneden. En zoo gaat langzamerhand de stam dood.

Niet alle boomsoorten zijn er even vatbaar voor om door "t roode vuur" te worden aangetast, wanneer men bij den snoei takstompjes laat zitten. 't Zijn onder de laan- en plantsoenboomen vooral iepen, paardekastanjes, acacia's (Robinia), walnoten, Pterocarpia's en verschillende soorten van eschdoorns, die er veel van te lijden hebben. Dat zijn in ' $t$ algemeen die boomsoorten, in welke de oorspronkelijk saprophytisch levende Nectria cinnabarina ook zeer gemakkelijk parasitair leeft, zoo zelfs dat zij zich in een gaven stam of tak gemakkelijk vestigt, als er maar een klein wondje is, waardoorheen zij kan binnendringen. Daarom is het altijd gewenscht, dat men ook als een tak op de juiste manier is weggenomen (zie figuur $B$, bij $p^{\prime}$ ) toch de wondvlakte met teer bestrijkt.

J. Ritzema Bos. 